\title{
THE 'ACQUIS' OF THE COUNCIL OF EUROPE IN THE SPHERE OF DISASTER PREPAREDNESS AND RESPONSE
}

\begin{abstract}
The article discusses institutional and standard-setting initiatives of the Council of Europe aimed at enhancing the effectiveness of its members states' actions when responding to natural or man-made disasters. Although the Statute of the Council of Europe itself is silent on tasks in this regard, the organization's agenda in disaster preparedness and response was developed inter alia through the EUR-OPA Major Hazards Agreement of 1987 (a so-called 'enlarged partial agreement'), as well as soft-law standards and the jurisprudence of the European Court of Human Rights on the positive obligations of states under Article 2 of the European Convention on Human Rights (the right to life). The article studies the Council of Europe's activities in this sphere, while noting - in a comparative perspective - the most important developments in international cooperation aimed at disaster prevention and response within the European Union, the Organization of Security and Co-operation in Europe, as well as the United Nations and the International Federation of Red Cross and Red Crescent.
\end{abstract}

\section{Keywords}

Council of Europe - partial and enlarged agreements - disaster preparedness - disaster response - international disaster law - EUR-OPA Major Hazards Agreement European Court of Human Rights

* Associate Professor, Human Rights Department, Faculty of Law, Nicolaus Copernicus University (Torun, Poland), e-mail: michal.balcerzak@umk.pl; ORCID: 0000- 


\section{INTRODUCTION}

Multiple international organizations - both global and regional - have undertaken initiatives in order to better co-ordinate response to natural and man-made disasters. In fact, the first two decades of the XXI century could be considered as an "awakening" of the international community which recognized the need to develop and strengthen the legal framework of disaster prevention, preparedness, and response. On the global level, some notable developments have taken place within the International Federation of the Red Cross and Red Crescent, with the adoption of standards known as International Disaster Response Laws ${ }^{1}$. Within the United Nations, the International Law Commission (ILC) has elaborated the Articles on the protection of persons in the event of disasters ${ }^{2}$, which were submitted to the Sixth Committee of the General Assembly of the United Nations. The Articles constitute an important point of reference in establishing the duties of states in times of disasters, as well the corresponding rights of those affected. The ILC recommended that states consider the Articles as a basis for a future hard-law instrument, i.e. a treaty. The reactions of UN member states to this proposal were diverse, although there is no doubt that the ILC's Articles serve as a vital orientation point in identifying the basic norms of international disaster law as it stands today.

0002-6421-1742. The article was prepared as part of the project financed by the Polish National Science Centre (grant no. 2014/15/B/HS5/03160): International law aspects of natural and man-made disasters, including their consequences for the protection of human rights.

1 See the Guidelines for the domestic facilitation and regulation of international disaster relief and initial recovery assistance (IDRL Guidelines) adopted at the $30^{\text {th }}$ International Conference of the Red Cross Movement. These Guidelines form an important, albeit not the one and only, point of reference as regards the standards of disaster law response elaborated by the IFRC. See also C. Clement, International Disaster Response Laws, Rules, and Principles: A Pragmatic Approach to Strengthening International Disaster Response Mechanisms In: D. Caron, M.J. Kelly, A. Telesetsky (eds), The International Law of Disaster Relief, Cambridge University Press 2014, pp. 67-88.

${ }^{2}$ Draft Articles on the protection of persons in the event of disasters (2016). Report of the International Law Commission of its sixty-eighth session. A/71/10. United Nations: New York, pp. 13-17. 
The interest of the United Nations in co-ordinating disaster preparedness and response goes widely beyond being a law-making exercise and involves procedures and activities aimed at providing immediate relief and assistance to those in need. Of particular importance in this regard are the activities of the Office of Coordination of Humanitarian Assistance (OCHA), the Emergency Response Coordinator (ERC), and the InterAgency Standing Committee (IASC), which are the principal parts of the UN system in leading, coordinating and facilitating humanitarian assistance ${ }^{3}$. It is also noteworthy that apart from practical action and field operations in a disaster context, there has been much debate within the UN and academia about the human rights-based approach to postdisaster assistance. By way of example, in 2015 a research-based report of the Human Rights Council Advisory Committee on best practices and main challenges in the promotion and protection of human rights post-disaster and post-conflict was submitted to the attention of the UN member states ${ }^{4}$. There has also been a plethora of interesting academic concepts on how to approach the axiological underpinnings of the humanitarian system, including in times of disasters ${ }^{5}$.

While the initiatives undertaken at a global level in the sphere of disaster prevention and response attract understandable attention, one should not overlook that some regional international organizations are also appropriate fora for elaborating standards and addressing situations identified as disasters. One of the most visible example from outside the European continent are the activities of the Association of SouthEast Asian Nations (ASEAN), which adopted an Agreement on Disaster

3 Their mandate originates in the resolution of the General Assembly no. 46/182, adopted on 19 December 1992 ('Strengthening of the coordination of the humanitarian emergency assistance of the United Nations').

4 See the Final research-based report of the Human Rights Council Advisory Committee, document no. A/HRC/28/76. The report was requested by the Human Rights Council in its resolution 22/16, adopted on 21 March 2013.

${ }^{5}$ See an interesting proposal for recognizing the principle of "humanitarian subsidiarity" in order to ensure a better effectiveness of the humanitarian actions: P. Gibbons, D. Roughneen, R. McDermott, S. Maitra, Putting Affected People at the Centre of Humanitarian Action: An Argument for the Principle of Humanitarian Subsidiarity, "Disasters" 2019 (accepted for publication, https://doi.org/10/1111/disa.12386). 
Management and Emergency Response in $2005^{6}$. In the European context, there exists an elaborated legal mechanism for providing support in case of disaster among member states of the European Union ${ }^{7}$. Also the Organisation for Security and Co-operation in Europe noted the challenges posed by natural disasters in the area of security, and decided to strengthen the organization's activities with regard to disaster risk reduction ${ }^{8}$.

Against this background, the activities of the Council of Europe - the oldest regional European organization with 47 member states - with respect to disaster prevention and response may seem to be less in the mainstream of what is known as "international disaster law". However, it is worth recalling that apart from the institutional and standard-setting initiatives referred to below, an important part of the Council of Europe's acquis in the sphere of disaster preparedness and response could be identified within the human rights law standards developed by this organization. They include also quite significant developments in the case-law of the European Court of Human Rights, which pronounced on the concept of the positive obligations of state-parties to the European Convention on Human Rights (ECHR) in the area of the right to life (Article 2) and protecting individuals from life-threatening hazards.

\section{EUR-OPA Major Hazards Agreement}

The Statute of the Council of Europe stipulates that the actions required to further the aim of the organization may be considered and undertaken by

${ }^{6}$ ASEAN Document Series 2005, p. 15. For further examples of regional and subregional co-operation in this regard see A. de Guttry, Surveying the Law, w: A. de Guttry, M. Gestri, G. Venturini (red.) “International Disaster Response Law”, Springer: Berlin 2012, p. 17 et seq.

7 See in particular the Decision No. 1313/2013/EU of the European Parliament and of the Council of 17 December 2013 on a Union Civil Protection Mechanism (OJIL L 347/924); EU Council Decision 2014/415 on the arrangements for the implementation by the Union of the solidarity clause (OJEU L 192/53), as well as the EU Council Regulation 2016/369 on the provision of emergency support within the Union (OJEU L 10/1).

8 See the decision no. 6/14 of the Ministerial Council of the OSCE, adopted on 5 December 2014 ('Enhancing Disaster Risk Reduction'). 
the Committee of Ministers via the conclusion of conventions or agreements and the adoption by governments of a common policy with regard to particular matters ${ }^{9}$. According to Article 15.b of the Statute, the conclusions of the Committee may take the form of recommendations to the governments of members, and the Committee may request the governments of members to inform it of the action taken by them with regard to such recommendations. Thus, the list of types of legal instruments adopted within this organization to achieve its aims is not long and includes classic international conventions, common policies as well as soft-law instruments, i.e. recommendations ${ }^{10}$.

The list referred to above is not exhaustive as the practice of the Council of Europe has developed also other forms of co-operation, and notably 'partial' and 'enlarged' agreements. These are not legal instruments per se but rather modalities of joint actions undertaken by part of the organization's member states, sometimes opened also for nonmembers ("enlarged partial agreements") or by all member states with one or more non-member states ("enlarged agreements"). The Committee of Ministers of the Council of Europe adopted certain basic rules on setting up partial and enlarged agreements very soon after establishing the organization itself: the resolution 51(62) allowed member states to abstain from participating in a course of action advocated by other states, without prejudice to the validity of such action for those in agreement. But it was not until 1993 that a statutory resolution $93(28)^{11}$ was adopted which clarified the rules of establishing partial and enlarged agreements, and provided that following an authorisation of the Committee of Ministers, a partial agreement or enlarged agreements can be established with a resolution containing the statute of the agreement, adopted only by those states that wish to do $\mathrm{so}^{12}$.

9 See Article 15 of the Statute of the Council of Europe, CETS no. 1.

${ }^{10}$ See on the soft-law instruments in the area of humanitarian assistance: D. Cubie, An Analysis of Soft Law Applicable to Humanitarian Assistance: Relative Normativity in Action?, "International Humanitarian Legal Studies", vol. 2, 2011, pp. 177-215.

${ }^{11}$ Statutory resolution (93)28 on partial and enlarged agreements, adopted by the Committee of Ministers on 14 May 1993 at its $92^{\text {nd }}$ session.

12 Some further criteria for establishing partial or enlarged agreements were set forth in Resolution (96)36, as amended by Resolution CM/Res(2010)2. According to the latter resolution, a new partial agreement requires the participation of at least one third of the member states of the Council of Europe. 
As of 2019, the list of partial agreements includes only two such initiatives ${ }^{13}$, a further two with an 'enlarged' status ${ }^{14}$, and ten qualified as 'enlarged partial' ones ${ }^{15}$. The Council of Europe's initiative which is central from the perspective of disaster preparedness and response is the enlarged partial agreement known as Co-operation Group for the Prevention of, Protection Against, and Organisation of Relief in, Major Natural and Technological Disasters. It was established by the resolution (87)2 of the Committee of Ministers, adopted in 1987 with eight founding member states, $^{16}$ and a current total number of participating $\mathrm{CoE}$ members amounting to twenty-two, plus several non-CoE member states and international organizations ${ }^{17}$. The Agreement of 1987 set up a group 'to make a multidisciplinary study of the co-operation methods for the prevention of, protection against, and organisation of relief in, major natural and technological disasters', acting through meetings at ministerial level and also through 'permanent correspondents'. Among the forms of activities of the Group the resolution mentions the organisation of relief (doctrines, information, simulation, assistance, etc.), as well as training and research.

Contemporarily, the agreement establishing the Co-operation Group has transformed into a 'European and Mediterranean Major Hazards Agreement (EUR-OPA)', but in legal terms its basis has remained the

${ }^{13}$ I.e.: European Pharmacopoeia (see the Convention on the Elaboration of a European Pharmacopoeia, ETS No. 050) and a 'forsaken' agreement on an European Card for Substantially Handicapped Persons.

${ }^{14}$ Including the very recognizable European Commission for Democracy through Law (the Venice Commission) and the Group of States against Corruption (GRECO).

15 This list includes: Council of Europe Development Bank, Co-operation Group to Combat Drug Abuse and Illicit Trafficking in Drugs, Co-operation Group for the Prevention of, Protection Against, and Organisation of Relief in Major Natural and Technological Disasters, European Support Fund for the Co-Production and Distribution of Creative Cinematographic and Audiovisual Works "Eurimages", European Centre for Global Independence and Solidarity (North-South Centre), Partial Agreement on Youth Mobility through the Youth Card, European Audiovisual Observatory, European Centre for Modern Languages, Enlarged Partial Agreement on Sport (EPAS), Enlarged Partial Agreement on Cultural Routes.

${ }^{16}$ France, Greece, Italy, Luxembourg, Malta, Portugal, Spain, and Turkey.

17 Non-CoE members include Algeria, Lebanon, and Morocco. One non-CoE state has an observer status (Japan). The European Union, the International Federation of Red Cross and Red Crescent Societies, the UN Office for Co-ordination of Humanitarian Assistance, UNESCO, and the WHO have the status of participants. 
same since 1987. It is supposed to facilitate 'co-operation in the field of major natural and technological disasters between Europe and the South of the Mediterranean'. Institutionally, the Agreement is enforced by Ministerial Meetings held every four years, with the assistance of the Committee of Permanent Correspondents who meet yearly. The heart of the Agreement involves a network of twenty-six Specialised Euro-Mediterranean Centres which are supposed to conduct research, improve awareness, and provide scientific and technical feedback aimed at disaster risk reduction, preparedness, and response ${ }^{18}$. The meetings of the directors of Specialized Euro-Mediterranean Centres are held yearly, together with the Committee of Permanent Correspondents.

With respect to the outcomes of EUR-OPA's activities, it should be mentioned that they are reflected in the resolutions and recommendations of the Committee of Permanent Correspondents, as well as other sorts of practical initiatives aimed at enhancing the member states' disaster preparedness and response. The resolutions are in fact not very numerous and they mainly set out the political aims of the agreement, as well as adopt medium term plans which are later confirmed by ministerial meetings ${ }^{19}$. The recommendations however focus on specific issues, such as inclusion of migrants, asylum seekers, and refugees, as well as people with disabilities, in disaster preparedness and response ${ }^{20}$; ecosystem-based disaster risk reduction ${ }^{21}$, or information to the public on radiation risks ${ }^{22}$.

\section{EUR-OPA'S ETHICAL PRINCIPLES RELATING TO DISASTER RISK REDUCTION AND CONTRIBUTING to People's Resilience to Disasters}

One of the most curious - though somehow controversial - examples of EUR-OPA's activities in the area of standard-setting are the 'Ethical

\footnotetext{
${ }^{18}$ For the full list see: www.coe.int/en/web/europarisks/specialised-centres.

19 See the resolution 2016(1) of the Committee of Permanent Correspondents.

${ }^{20}$ See, respectively, the recommendations of Committee of Permanent Correspondents

${ }^{21}$ See the recommendation 2012(1).

22 See the recommendation 2011(1).
} 2016(1) and 2013(1). 
Principles relating to Disaster Risk Reduction and contributing to People's Resilience to Disasters'. Prior to analysing these sets of principles, a couple of words are necessary to explain their genesis and legal character. To deal with the latter first, one should refer to Resolution 2011(1) of the Committee of Permanent Correspondents, which considered the appended text of the principles (prepared by Professor Michel Prieur) as 'a compilation of existing ethical principles related to disaster risk reduction and as an evolutionary text without a normative character ${ }^{23}$. Further, in the same resolution, the CPC invited the member states of the Agreement (i.e. EUR-OPA) to 'take account as appropriate of the appended ethical principles' and 'update the document regularly' ${ }^{24}$. In essence, the text of the 'Principles' seems to have been recommended by the CPC of the Agreement in extremely cautious terms ('inviting to take account of').

Also, the resolution described the text as a 'compilation of existing ethical principles (...) without a normative character'. This description in itself requires a short commentary. What was probably meant here was that the text of 'principles' has no binding force rather than lacks any normativity. It is essential that binding force is not to be confused with normative character. In fact, ethics is a normative system, though its norms are neither formally binding, nor are they necessarily a matter of a common consent. Also, one cannot assume that ethical norms are always transformed into the language of legally binding norms. But irrespective of these considerations, the very attempt to 'compile existing ethical principles' applicable in the sphere of disaster preparedness and response seems to be an extremely ambitious task. The whole area of international disaster law sensu largo - i.e. norms referring to international co-operation on every phase of the so-called 'disaster-cycle' as well as the rights and duties of affected states, groups and individuals - obviously does include certain axiological underpinnings. Providing humanitarian assistance is also governed by certain principles of a theoretical or axiological provenance. However, very few - if any - international standard-setting initiatives in the area of international disaster law have attempted to

${ }^{23}$ See the resolution of CPC 2011(1), adopted at the $60^{\text {th }}$ meeting of the CPC in Strasbourg, on 15 April 2011.

${ }^{24}$ Ibidem. 
deal with the ethical or moral obligations of various parties involved in providing or receiving assistance in a disaster context. An assessment of whether or not the 'principles' do indeed constitute a compilation of ethical norms, will be provided below. But prior to that, some further explanations are required as to the legal status and genesis of the text.

From a purely formal or technical perspective, the text of the 'Principles' was elaborated by the Executive Secretariat of EUR-OPA, ${ }^{25}$ while the CPC's resolution 2011(1) indicated the principal author who drafted the text (Prof. Michel Prieur). Commissioning external opinions, drafts, or compilations is not uncommon within the Council of Europe's standard-setting activities. In this case however, it appears that the draft text was not the subject of deliberations or negotiations between the member states of the Agreement. A somewhat different practice exists with soft-law instruments such as the recommendations of the Committee of Ministers of the Council of Europe. Although also not formally binding, such recommendations are usually firstly drafted and discussed in inter-governmental working groups and/or steering committees, to be subsequently reviewed and adopted by the Committee itself. Without prejudice to their content and value, the 'Principles' discussed in this subsection do not have the same status as recommendations of the Committee of Ministers. They should rather be considered as an auxiliary proposal of standards endorsed by Committee of Correspondents of EUR-OPA, while not elaborated by the states themselves.

As to the genesis of the 'Principles': their introduction refers to the Parliamentary Assembly of the Council of Europe's Recommendation $1862(2009)^{26}$ as the primary source of inspiration. The said recommendation concerned environmentally induced migration and displacement -

${ }^{25}$ Prior to adoption by the CPC, the text of the 'Principles' was considered a draft. Its full text has been included in document AP.CAT(2011))02 Rev., dated 7 April 2011. The 'Principles' were subsequently published as M. Prieur, Ethical Principles on Disaster Risk Reduction and People's Resilience, European and Mediterranean Major Hazards Agreement (EUR-OPA), Council of Europe 2012, with a caveat: The opinions expressed in this work are the responsibility of the author(s) and do not necessarily reflect the official policy of the Council of Europe. The publication is available in public domain: www.coe.int/en/web/europarisks/ publications.

${ }^{26}$ Recommendation 1862(2009). Environmentally induced migration and displacement: a $21^{\text {st }}$ century challenge. 
i.e. issues having close affinity with consequences of natural disasters. The text of this recommendation actually does not include any 'invitation to prepare an ethical charter on resilience to disasters', as suggested by the introduction to the 'Principles', but irrespective of the above, the state parties of EUR-OPA expressed interest in elaborating on 'ethical principles' during the $12^{\text {th }}$ Ministerial Session of the EUR-OPA Major Hazards Agreement held in St. Petersburg in 2010.

With respect to the contents of the 'Principles', one should start by observing that naming them 'Ethical principles' is somewhat confusing, mostly because the 'principles' compile legal rather than ethical standards and one cannot escape an impression that the term 'ethical' was either used as a synonym to "non-binding" and/or as a way to achieve consensus and ensure that the text would not raise major objections on the part of the states. Regardless of the motivation, the choice of the term 'ethical principles' seems to be a very unorthodox one. The terms 'guidelines' or 'recommended standards' would be better options, as the term 'ethical principles' simply does not properly reflect the contents. A considerable number of the 'principles' are legal, with some referring to ethical and general issues as well as recommended good practices. The 'Foreword' to the 'Principles' states that they should give rise to the a culture of resilience associated with a systematic consideration of human rights, everywhere and at all times, thus contributing to the development of a 'moral code' applicable just as well to disaster prevention as to emergency situations during the disaster itself ${ }^{7}$. Once again, it should be observed that the aims of this document were particularly ambitious.

The text is divided into an introduction and four parts: general principles (part I) and the 'ethical principles' applied prior (II), during (III), and after disasters (IV). Under the 'general principles' heading, the drafters included several concepts and/or principles, some of which are universally recognized as general principles of humanitarian assistance (humanity, impartiality, neutrality), some are widely known principles of human rights law (non-discrimination) or international law (territorial sovereignty), and some reflect basic ideas of international relations (solidarity). Certain concepts could be regarded as particularly important

${ }^{27}$ M. Prieur, Ethical principles..., p. 9. 
in the area of disaster awareness and response: 'prevention' and 'the role of the media'. In general, the concepts referred to above are part and parcel of universal standards regarding disaster response law and many of them could be also characterized as having legal and not (only) ethical provenance.

The further parts of the document - concerning the different phases of the 'disaster cycle' - constitute a collection of guidelines and good practices. With respect to the principles applied during disasters, the document refers inter alia to humanitarian assistance, information and participation during disasters, compulsory evacuation of populations, respect for dignity and personal rights, emergency assistance for the most vulnerable persons, the importance of rescue workers, and measures to safeguard and rehabilitate the environment as well as to safeguard and restore social ties. The last part of the 'principles' - applicable in the post-disaster phase - emphasises the protection of all categories of rights: economic, social, and cultural as well as civil and political. These 'reminders' have in fact a strictly legal rather than ethical dimension, as they concern the binding international obligation of states affected by disasters to ensure the protection of human rights. This protection does not cease in times of disaster, notwithstanding the difficulties in fulfilling some treaty obligations due to extraordinary circumstances.

Summing up, the 'principles' are a compilation of guidelines, good practices, as well as references to the duties of states and particularly sensitive areas of disaster management. While being rather general and imprecisely referring to the sphere of ethics, the compilation does have a certain informative and educational value. Apparently the member states of EUR-OPA did not intend this text to be a result of inter-governmental works in order to expand it and/or detail its contents. The 'principles' are therefore less detailed and authoritative than, for instance, the Operational Guidelines on the Protection of Persons in Situations of Natural Disasters adopted by the UN Inter-Agency Standing Committee ${ }^{28}$ or the IDRL Guidelines for the domestic facilitation and regulation of international disaster relief and initial recovery assistance ${ }^{29}$. But irrespective of the above, the

28 See Operational Guidelines on the Protection of Persons in Situations of Natural Disasters, The Brookings - Bern Project on Internal Displacement 2011.

${ }^{29}$ See footnote no. 2. 
'principles' can be regarded as a first step towards a more elaborated set of standards. It is also noteworthy that the references to standards applicable in times of disasters are sometimes included in recommendations of the Committee of Ministers of the Council of Europe concerning climate changes and cultural heritage ${ }^{30}$. Further, the risks of environmental disasters were also a subject of debate within the Parliamentary Assembly of the Council of Europe ${ }^{31}$.

\section{CASE-LAW of the European Court OF HUMAN RIGHTS}

This brief review of the Council of Europe's acquis concerning disaster preparedness and response needs to be supplemented by some remarks on the case-law of the European Court of Human Rights (ECtHR). Its judicial activity constitutes one of the most vital points of reference in discussing European human rights law, even though the Court itself is not a statutory body of the Council of Europe, but an international court established under the European Convention on Human Rights of 1950 (ECHR $)^{32}$. In fact, neither the Convention nor its Protocols include any specific provisions referring to the obligations of states, and the corresponding human rights in times of disasters and events of this kind do not alter the scope of responsibility of state parties. However, in theory, a disaster reaching the threshold of a 'public emergency threatening the

30 See the recommendations: $\mathrm{CM} / \operatorname{Rec}(2018) 3$ of the Committee of Ministers to member States on cultural heritage facing climate change: increasing resilience and promoting adaptation, as well as $\mathrm{CM} / \operatorname{Rec}(2017) 1$ on the European Cultural Heritage Strategy for the 21st century. The latter recommendation stipulates under the 'General Framework' heading: Demographic and climate changes, the spread of mass tourism at global level, the growing number of natural or man-made disasters, the temptation of community isolationism, intergenerational divisions, the economic crisis and the emergence of challenges to or serious violations of the values of freedom, tolerance, and democracy on which our societies are based: all these challenges call for coherent, comprehensive, and inspiring responses.

31 See the Recommendation of the Parliamentary Assembly no. 1823(2008) on global warming and ecological disasters, adopted on 22 January 2008.

32 Convention for the Protection of Human Rights and Fundamental Freedoms, signed in Rome on 4 November 1950, European Treaty Series no. 005. 
life of the nation' in the meaning of Article 15 of the ECHR could be a basis for derogating certain human rights obligations under the so-called 'derogation clause' ${ }^{33}$. Fortunately, so far no invocation of Article 15 in this context has ever happened following a disaster on the territories of state parties to the ECHR.

A reference to 'service exacted in case of an emergency or calamity threatening the life or well-being of the community' forms part of the 'negative' definition of 'forced or compulsory labour' enshrined in Article 4 of the Convention ${ }^{34}$. In other words, the notion of compulsory labour (which in itself is prohibited under Article 4(2) of the ECHR) does not include service required after a disastrous event that constitutes a threat to the life or well-being of the population. There has not been any case at the European Court of Human Rights which would concern this particular 'exception'. Instead, the Court had an opportunity to adjudicate certain cases in which a loss of life following a disaster was considered as attributable to the respondent state and as a violation of the latter's obligation under Article 2 of the Convention (right to life).

Two judgments of the ECtHR are particularly relevant in this regard: Öneryıldız v. Turkey ${ }^{35}$ and Budayeva and others v. Russian Federation ${ }^{36}$. The first one concerned deaths of the applicants' close relatives and destruction of their property following a methane explosion in 1993 at a municipal rubbish tip. The second case followed from a mudslide in a Russian town of Tyrnauz which caused eight fatalities in 2000. Both cases were adjudicated in the light of the positive obligation of state parties to the ECHR under Article 2 of the Convention. Having recalled that the protection of the right to life under this provision does not concern solely deaths resulting from the use of force by state agents, but also lays down a positive obligation on states to take appropriate steps to safeguard the lives of those under its jurisdiction, the Court went on to stress that this obligation

${ }^{33}$ See more on this issue: E. Sommario, Limitation and Derogation Provisions in International Human Rights Law Treaties and Their Use in Disaster Settings, [in:] F.Z. Giustiniani, E. Sommario, F. Casolari, G. Bartolini (eds) Routledge Handbook on Human Rights and Disasters, Routledge: London-New York 2018, pp. 98-118.

${ }^{34}$ See Article 4(3)(c) of the ECHR ('Prohibition of slavery and forced labour').

35 Judgment of 30 November 2004, application no. 48939/99.

36 Judgment of 20 March 2008, applications no.: 15339/02, 21166/02, 20058/02, $11673 / 02,15343 / 02$. 
(i.e. the positive one under Article 2 of the ECHR) indisputably applies in the particular context of dangerous activities, where, in addition, special emphasis must be placed on regulations geared to the special features of the activity in question, particularly with regard to the level of potential risk to human lives. $(. . .)^{37}$.

In the particular circumstances of the Önerylld $z$ case the Court found that there had been a violation of Article 2 of the Convention on account of the lack of appropriate steps to prevent the accidental death of nine of the applicant's close relatives. Further, the Court held that the above provision of the Convention had been violated also owing to inadequate protection by the law safeguarding the right to life, i.e. under the 'procedural' limb of Article 2.

In the Budayeva and others judgment the Court generally followed its case-law on 'dangerous activities' in the context of natural or man-made disasters, reaffirming inter alia that:

in the sphere of emergency relief, where the State is directly involved in the protection of human lives through the mitigation of natural hazards, these considerations should apply in so far as the circumstances of a particular case point to the imminence of a natural hazard that had been clearly identifiable, and especially where it concerned a recurring calamity affecting a distinct area developed for human habitation or use. (...) The scope of the positive obligations imputable to the State in the particular circumstances would depend on the origin of the threat and the extent to which one or the other risk is susceptible to mitigation..$^{38}$

Also in Budayeva and others the Court ruled in favour of the applicants as regards the violation of their rights under Article 2, i.e. with respect to Russia's failure to discharge its positive obligations to protect the right to life as well as on account of the lack of an adequate judicial response as required in the event of alleged infringements of that right ${ }^{39}$. However,

37 See $\S 90$ of the Öneryıldız judgment. In the same paragraph the Court observed that (...) particular emphasis should be placed on the public's right to information, as established in the case-law of the Convention institutions. The Grand Chamber agrees with the Chamber (...) that this right, which has already been recognised under Article 8 (...), may also, in principle, be relied on for the protection of the right to life, particularly as this interpretation is supported by the current developments in European standards (...).

${ }^{38}$ See $\S 137$ of the Budayeva judgment.

39 See $\S \S 1$ and 2 of the dispostitive part of the Budayeva judgment. 
the conclusion of the two judgments referred to above, Öneryıld $z$ and Budayeva, differed as regards the allegations under Article 1 of Protocol no. 1 (the right to peaceful enjoyment of possessions). The ECtHR found a violation of this provision only in the Turkish case, whereas examining the Russian one in part concerning the destruction of the applicants' flats, the Court held that:

in a situation where lives and property were lost as a result of events occurring under the responsibility of the public authorities, the scope of measures required for the protection of dwellings was indistinguishable from the scope of those to be taken in order to protect the lives of the residents. Treatment of waste, a matter relating to industrial development and urban planning, is regulated and controlled by the State, which brings accidents in this sphere within its responsibility. Accordingly, the Court concluded that the authorities were required to do everything within their power to protect private proprietary interests (...)

In the present case, however, the Court considers that natural disasters, which are as such beyond human control, do not call for the same extent of State involvement. Accordingly, its positive obligations as regards the protection of property from weather hazards do not necessarily extend as far as in the sphere of dangerous activities of a man-made nature ${ }^{40}$.

Distinguishing between natural and man-made/industrial disasters in the context of the protection under the Convention has been criticised by some authors ${ }^{41}$ as being erroneous and not taking into account that modern disaster research offers a different view on these type of events through social concepts of vulnerability, resiliency, and risk rather than the distinction between 'natural' and 'non-natural'. This criticism was based on solid grounds, although it appears that this differentiation matters for the Court in particular as regards the obligation of states with respect to the protection of property. It does not seem that the positive obligations stemming from Article 2 of the Convention are necessarily different or weaker in the case of protection against natural hazards as

${ }^{40}$ See $\S \S 173-174$ of the Budayeva judgment.

${ }^{41}$ See. K.C. Lauta, J.E. Rytter, A Landslide on a Mudslide? Natural Hazards and the Right to Life under the European Convention on Human Rights, "Journal of Human Rights and the Environment", vol. 7, issue 1, 2016, pp. 111-131. 
juxtaposed to anthropogenic or industrial ones. Nevertheless, there is much sense in the quoted authors' argument that it is not the origin of the hazard that should determine the scope of the preventive obligations of states, but the foreseeability, gravity, and mitigability of the threat ${ }^{42}$.

In any event, the ECtHR established some rules on assessing the positive obligations of states as regards protecting life and well-being in times of disasters, including with respect to the protection of property. These rules are part of a continuously expanding number of adjudicated cases concerning the environment and its implication for the rights and freedoms enshrined in the Convention. A compilation of these cases was included in a 'factsheet' prepared by the Registry of the Court ${ }^{43}$; a more expanded publication (a 'manual') summarizing the Council of Europe's acquis in the sphere of environment and human rights was also elaborated within the Steering Committee of Human Rights $(\mathrm{CDDH})^{44}$.

\section{CONCLUSIONS}

Even if not in the centre of the Council of Europe's contemporary agenda, the issues related to disaster preparedness and response, as well as international co-operation in disaster prevention and providing relief, can be considered as an area of interest for at least half of the member states who participate in the activities of the EUR-OPA Major Hazards Agreement. The standard-setting initiatives of EUR-OPA are relatively modest, but they can potentially develop into more elaborate legal acts. One should appreciate the efforts of EUR-OPA, particularity in the domain of awareness raising and of networking between the twenty-six Specialised Euro-Mediterranean Centres. Other important elements of the Council of Europe's acquis in this sphere are the recommendations

42 Ibidem.

43 See the factsheet 'Environment and the European Convention on Human Rights", dated November 2019, available at: www.echr.coe.int/Documents/FS_Environment_ENG. pdf (visited: November 2019).

${ }^{44}$ See 'Manual on human rights and the environment', Council of Europe Publishing 2012, available at: www.echr.coe.int/LibraryDocs/DH_DEV_Manual_Environment_Eng. pdf (visited: November 2019). 
of the Committee of Ministers and of the Parliamentary Assembly, as well as the case-law of the European Court of Human Rights in cases involving pre- or post-disaster context.

At present there seems to be no intention on the part of the member states of the Council of Europe to proceed with any more far-reaching legal instruments concerning disaster prevention and response. One should bear in mind however that there already exist quite a number of bilateral treaties on mutual assistance in times of emergency, so there is no need to suggest a multilateral treaty under the auspices of the Council of Europe in this regard. Instead, it is of primary importance that the organization's indisputable achievements in the sphere of human rights are adequately taken into account in the discussions on the protection of human rights in times of disasters. One of the opportunities for including this perspective arises in the works of the International Law Association's Committee on Human Rights in Times of Emergency established in $2017^{45}$. This committee is due to present its final report at the ILA's conference in Lisbon in 2022.

45 See the mandate of the ILA Committee on Human Rights in Times of Emergency, available at ILA's website: www.ila-hq.org/index.php/committees (accessed: November 2019). 